
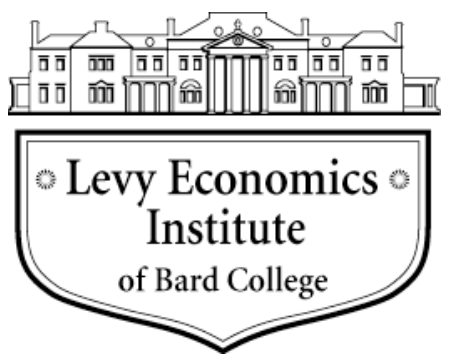

Working Paper No. 652

\title{
The Dismal State of Macroeconomics and the Opportunity for a New Beginning
}

\author{
by \\ L. Randall Wray \\ Levy Economics Institute of Bard College
}

March 2011

The Levy Economics Institute Working Paper Collection presents research in progress by Levy Institute scholars and conference participants. The purpose of the series is to disseminate ideas to and elicit comments from academics and professionals.

Levy Economics Institute of Bard College, founded in 1986, is a nonprofit, nonpartisan, independently funded research organization devoted to public service. Through scholarship and economic research it generates viable, effective public policy responses to important economic problems that profoundly affect the quality of life in the United States and abroad.

Levy Economics Institute P.O. Box 5000

Annandale-on-Hudson, NY 12504-5000

http://www.levyinstitute.org 


\begin{abstract}
The Queen of England famously asked her economic advisers why none of them had seen "it” (the global financial crisis) coming. Obviously, the answer is complex, but it must include reference to the evolution of macroeconomic theory over the postwar periodfrom the "Age of Keynes," through the Friedmanian era and the return of Neoclassical economics in a particularly extreme form, and, finally, on to the New Monetary Consensus, with a new version of fine-tuning. The story cannot leave out the parallel developments in finance theory - with its efficient markets hypothesis—and in approaches to regulation and supervision of financial institutions.

This paper critically examines these developments and returns to the earlier Keynesian tradition to see what was left out of postwar macro. For example, the synthesis version of Keynes never incorporated true uncertainty or "unknowledge," and thus deviated substantially from Keynes's treatment of expectations in chapters 12 and 17 of the General Theory. It essentially reduced Keynes to sticky wages and prices, with nonneutral money only in the case of fooling. The stagflation of the 1970s ended the great debate between “Keynesians” and "Monetarists" in favor of Milton Friedman's rules, and set the stage for the rise of a succession of increasingly silly theories rooted in pre-Keynesian thought. As Lord Robert Skidelsky (Keynes’s biographer) argues, "Rarely in history can such powerful minds have devoted themselves to such strange ideas.” By returning to Keynes, this paper attempts to provide a new direction forward.
\end{abstract}

Keywords: Efficient Markets Hypothesis, Keynesian Economics, Orthodoxy, Heterodox Economics, Minsky, Uncertainty, Rational Expectations, New Classical, New Monetary Consensus, Monetary Theory of Production, Effective Demand, Special Properties of Money, the End of Laissez-Faire, Financial Instability Hypothesis

JEL Classifications: A2, B15, B22, B50, E11, E12, G01 
The Queen of England famously asked her economic advisors why none of them had seen "it" (the global financial crisis) coming. Obviously the answer is complex, but it must include reference to the evolution of macroeconomic theory over the postwar period-from the “Age of Keynes," through the Friedmanian era and the return of Neoclassical economics in a particularly extreme form, and finally on to the New Monetary Consensus with a new version of fine-tuning. The story cannot leave out the parallel developments in finance theory — with its efficient markets hypothesis—and in approaches to regulation and supervision of financial institutions. Even if the early postwar “Keynesian” economics had little to do with Keynes, at least it had some connection with the world in which we actually live. What passed for macroeconomics on the verge of the global financial collapse had nothing to do with reality. It is difficult to see that anything taught as macroeconomics in the best-selling textbooks in 2007 will survive. It is as relevant to our economy as flat Earth theory is to natural sciencewarranting a small footnote in the history of economic thought. In short, expecting the Queen's economists to foresee the crisis would be like putting flat Earthers in charge of navigation for NASA and expecting them to accurately predict points of reentry and landing of the space shuttle.

\section{POSTWAR DEVELOPMENT OF MAINSTREAM MACROECONOMICS}

Many authors have previously questioned the degree to which "Keynesian” theory and policy actually followed Keynes’s General Theory (GT). In 1937 John Hicks had created the ISLM model to present Keynes’s theory in a simple framework that could be used to compare "Keynesian” and "Classical” results. Immediately after the war, macroeconomists set out to "marry" the "Keynesian” ISLM model with the old preKeynesian microeconomic theory based on individual rational utility and profit maximization - in other words, on the neoclassical approach to the behavior of firms and consumers. ${ }^{1}$ Paul Samuelson called it the "Neoclassical Synthesis” and it became the

\footnotetext{
${ }^{1}$ Throughout this section I will provide only a brief overview of the main tenets of orthodox approaches, and will spare the reader detailed citations. Thorough summaries as well as references are provided in many commonly used macroeconomics textbooks. The Samuelson (1973) text is useful for the "Keynesian"
} 
foundation for macroeconomics taught in classrooms (Samuelson 1973). Macro theory continued to develop through the 1960s as James Tobin's portfolio balance approach, Don Patinkin's labor market, and the Phillips Curve were added to Hicks's ISLM model (see Patinkin 1965 and Minsky 1986). Likewise, “Keynesian” policy gradually developed over the postwar period, finally taking hold in the administration of President Kennedy. And Milton Friedman developed Monetarism as a "laissez faire" counterpoint (Friedman 1969; Brunner 1968). Still, even his approach was easily integrated within the Neoclassical Synthesis so that the "great debate" between "Keynesians" and "Monetarists" was reduced to differences over parameters (interest rate elasticity of investment and income elasticity of money demand) and policy prescriptions (discretionary interest rate targets or money growth rules).

Yet many important aspects of Keynes’s GT were absent (Keynes 1964). For example, the synthesis version of Keynes never incorporated true uncertainty or "unknowledge," and thus deviated substantially from Keynes's treatment of expectations in chapters 12 and 17 of the GT. It essentially reduced Keynes to sticky wages and prices, with non-neutral money only in the case of fooling. ${ }^{2}$ The stagflation of the 1970s ended the great debate between "Keynesians" and “Monetarists" in favor of Milton Friedman's rules, and set the stage for the rise of a succession of increasingly silly theories rooted in pre-Keynesian thought. As Lord Robert Skidelsky (Keynes’s biographer) argues “rarely in history can such powerful minds have devoted themselves to such strange ideas” (Skidelsky 2009: xiv).

First, New Classical theory restored the most extreme version of Neoclassical economics, with continual market clearing (including full employment) and "rational expectations" that ensures economic agents do not make persistent errors. This makes it impossible to fool rational actors in the manner Friedman supposed, since expectation formation is forward-looking and is based on the correct model of the economy. This also means that nonrandom policy has no effect at all because agents immediately figure out

neoclassical synthesis; for the post-1970s developments the text by Mankiw (2008) is good for undergraduates, while the Snowdon and Vane (2006) text provides a more advanced examination.

${ }^{2}$ Workers and/or firms would be fooled temporarily by an increase of nominal wages and prices, mistaking it for an increase of real wages or prices - thus, temporarily supplying more labor and/or output. This was supposed to be caused by an increase of the money supply. In the Lucas version, such "fooling" can occur only if the increase of the money supply is unanticipated (which requires that it is random and therefore unpredictable). 
what policymakers are doing and adjust their own behavior in an optimal manner. Money matters only temporarily, while agents gather the information necessary to distinguish real from nominal prices. Fiscal policy does not matter at all—for example, deficit spending is completely crowded-out because taxpayers know they will have to pay down government's debt later so begin saving immediately (Ricardian Equivalents). Still, New Classical theory's explanation of the business cycle depended on short-run non-neutrality of money (the misperception of rising nominal prices as rising relative prices).

Real Business Cycle theory took the final step to eliminate any effect of money by making the business cycle a function only of real variables. The most important is random and large fluctuations of productivity. In this way, the Great Depression was explained not as a fault of errant monetary policy—as Friedman had done—but rather as a negative productivity shock. Because workers were suddenly less productive, their real wage fell. At the lower real wages, they decided to take more leisure. This is suboptimal only if they misperceive a change of nominal wages as a change of real wages-a mistake that could only be temporary. Hence, involuntary unemployment did not rise during the Great Depression - rather, people took long vacations. All behavior is always optimal, all markets always clear-indeed, the observed business cycle is not a cycle at all, rather, the economy follows a "random walk with drift" (the economy follows a constant growth rate trend until it is shocked so that it instantly adapts to a new trend rate of growth). Government should not do anything about what we have called recessions or depressions because these are actually optimal responses to random shocks. You can see why Lord Skidelsky labels these theories "strange" - the suffering of the unemployed in the Great Depression was an "optimal” response because workers preferred standing in bread lines over working at lower real wages. Those who developed these ridiculous theories actually got Nobels for this work. ${ }^{3}$

Developments in finance theory mirrored the evolution of mainstream economic theory in the sense that like money, finance also became irrelevant (Fama 1970). So long as markets are efficient, all forms of finance are equivalent. Financial institutions are seen

\footnotetext{
${ }^{3}$ It is not commonly known that the Nobel in economics is actually awarded by the Bank of Sweden-the prize in economics is not a real Nobel Prize, but the economists who win do like to call themselves Nobel Laureates. Of course, that does not mean that their research is not worthy of an award.
} 
as intermediaries that come between savers and investors, efficiently allocating savings to highest use projects. Evolution of financial practices continually reduces the "wedge" between the interest rate received by savers and that paid by investors-encouraging more saving and investment. Domestic financial market deregulation (underway since the mid-1960s in the United States), as well as globalization of international financial markets, plays a key role in enhancing these efficiencies, and, hence, in promoting growth. The key conclusion is that if market impediments are removed, finance becomes "neutral." Further, markets will discipline financial institutions, hence, self-regulation is enough because it will align incentives to produce safe practices.

In recent years a "New" Neoclassical Synthesis (often called the "New Monetary Consensus") was developed, adopting most of the "strange ideas" but obtaining "Keynesian” style results by reviving sticky wages and prices. Again, Skidelsky nicely skewers the new orthodoxy: "Having swallowed the elephant of rational expectations, they strained at the gnat of the continuous full employment implied by it, and developed theories of market failure to allow a role for government” (Skidelsky 2009: xv). Unlike the early postwar Keynesian policy that advocated use of fiscal policy to fine-tune the economy, this version elevated monetary policy to that role. By this time, however, mainstream economists had given up on attempts by central banks to control the money supply—Friedman's preferred target—and replaced that with control over the interest rate (Wray 2004).

The goal was the same. Following a strategy known as the Taylor rule, the central bank would adjust its interest rate target based on deviation of actual inflation rates from targets as well as the output gap (differential between potential output and actual output). For example, if inflation is higher than desired and if actual output exceeds potential output, then the central bank raises interest rates to cool the economy. This is really just a slightly updated Phillips curve notion - if the unemployment rate gets too low, inflation results-but with far more concern shown for inflation than unemployment. Some advocates go a bit further, actually proposing specific inflation rate targets (completely ignoring unemployment outcomes) — with several central banks around the world explicitly adopting such targets. In any event, the belief is that all government really needs to do is to keep inflation low-by itself, that will promote robust growth that will 
keep the economy close to full employment. There is also the belief that monetary policy is highly potent—central banks can keep inflation on target (say, 1-2\% per year), which by itself will fine-tune the economy.

Mainstream economists thought it all worked splendidly through 2007. Central bankers around the world congratulated themselves for keeping inflation low. Fed Chairman Alan Greenspan was known as the "Maestro," and was proclaimed to be not only the greatest central banker ever, but also the most powerful human on earth. When he retired, the chairmanship mantle was handed over to Ben Bernanke, who promoted the idea of the "Great Moderation." By keeping inflation low, the world's central bankers had promoted economic stability (the "moderation"). Since everyone in the economy knew central bankers were committed to stability, all expected stability, and hence, we would have stability. All that was now necessary was to manage expectations. Markets knew the central banks would keep inflation low, and knew that if there were any economic hiccups, the central banks would quickly act to restore stability. That, itself, provided confidence-it was known as the "Greenspan put" and then as the "Bernanke put," the idea that the chairman of the Fed would prevent anything bad from happening. Real estate prices boomed, commodities prices bubbled, stock markets rose, and Wall Street’s financial institutions recorded terrific profits (Wray 2008a, 2009).

Well, it worked until it didn't—more precisely, it failed spectacularly beginning in spring 2007 as the world's economy slipped into the worst crisis since the 1930s (only a few nations escaped—notably, China, which had not allowed unfettered financial markets). The major central banks moved to reassure markets that they were in charge. Yet it became apparent that lowering interest rates—essentially to zero—had no impact. The crisis grew worse, with rising unemployment, falling retail sales, the worst collapse of real estate markets since the Great Depression, and with one financial institution failing after another. The Fed lent reserves, bought toxic waste assets, and guaranteed private institution liabilities, while the Treasury followed suit with its own bailouts, including effectively nationalizing the US auto industry. Total US government spending, lending, and guarantees (including those by the Fed and Treasury) grew to more than $\$ 20$ trillion (substantially larger than GDP)—all with little success (Cassidy 2008; Chancellor 2007; Wray 2009). As this paper was being written, more than three years into the crisis, 
many economists and policymakers were projecting a "double-dip"-that is, a collapse back into recession — and many argued that the biggest banks were still massively insolvent. So much for “Maestros” and “Great Moderations” and “laissez faire.”

The global crisis exploded reigning orthodoxy. Among those theories and claims that should no longer be taken seriously by any macroeconomist we must include: rational expectations and continuous market clearing; New Classical and Real Business Cycle approaches; neutral money; the New Monetary Consensus, the Taylor rule, and the Great Moderation; the Efficient Markets Hypothesis; Ricardian equivalents and other versions of the policy irrelevance doctrine; and claims made by advocates of deregulation and self-regulation. None of these ideas should be taught in any serious economics course-they are no more relevant to economic theory than are bloodletting techniques to the study of medicine.

To be sure, we have been here before. The Great Depression also exploded the reigning orthodoxy. Keynes offered a revolution in thought. Unfortunately, that revolution was aborted, or, at least, co-opted by "synthesizers” who borrowed only the less revolutionary aspects of his theory and then integrated these into the old Neoclassical approach. The important insights of Keynes were never incorporated in mainstream macroeconomics. Eventually, Neoclassical theory was restored. It is now time to throw it out, to see what should be recovered from Keynes, and to update Keynes's theory to make it relevant for the world in which we actually live.

\section{KEYNES'S REVOLUTION: THEORY AND METHODOLOGY}

The central proposition of the General Theory can be simply stated as follows: Entrepreneurs produce what they expect to sell, and there is no reason to presume that the sum of these production decisions is consistent with the full employment level of output either in the short run or in the long run (Forstater and Wray 2008). Moreover, this proposition holds even in conditions of perfect competition and flexible wages, even if expectations are always fulfilled, and even in a stable economic environment. In other words, Keynes did not rely on sticky wages, monopoly power, disappointed expectations, or economic instability (due, for example to “exogenous” shocks) to explain 
unemployment. While each of these conditions could certainly make matters worse, he wanted to explain the possibility of equilibrium with unemployment even under the conditions most favorable to the Neoclassical model.

Keynes’s approach begins with a focus on the entrepreneurial decision-each firm produces what it expects to sell-rather than on the consumer who maximizes utility through time. That entrepreneurial decision is based on a comparison between the costs incurred to produce now against the proceeds expected to be received in the future. A decision to produce is simultaneously a decision to employ and to provide incomes to workers. It probably also commits the firm to a stream of payments over some time period (since firms usually borrow to finance production costs). Production will not be undertaken unless the expected proceeds exceed by a sufficient margin the costs incurred today and into the future. Both the costs and the revenues accrue in the form of money. If the comparison of estimated costs and expected revenues is deemed unfavorable, production is not undertaken and income is not generated. There is no reason to believe that the result of all of these individual production decisions will be full employment of labor resources. Note also that because production begins and ends with money, Keynes rejects the notion of neutrality of money-in an important sense, the purpose of production is money (Keynes called this a monetary theory of production; Marx designated this M-C-M': the entrepreneur begins with money, produces commodities, and hopes to end up with more money). ${ }^{4}$

Keynes required only three conditions to ensure the possibility of equilibrium with unemployment: historical time, autonomous spending, and existence of a nonproducible store of value. With historical time, the past is more or less known, but cannot be changed; decisions taken today depend on outcomes that depend, in turn, on past decisions as well as on outcomes expected in the future, and the future cannot be known now. Each of these considerations represents an important deviation from most orthodox analysis. Mistakes cannot be easily eliminated through "recontracting”;

\footnotetext{
${ }^{4}$ This is not to say that orthodoxy has completely ignored money. Indeed, as discussed above, all but the Real Business Cycle approach tried to find a way to make money matter-that is, to make it "nonneutral." However, money was never introduced in a convincing manner-as Hahn's lament (cited below) makes clear. None of the orthodox approaches makes money the object of production. In Keynes's terminology, the subject of orthodox economics is not an entrepreneurial economy, so although money might be used it is not essential.
} 
hysteresis and cumulative causation are pervasive phenomena; decisions must be taken without the possibility of knowing what the future might bring. At least a portion of spending depends on expectations of the future, rather than on today's income-allowing individual spending to be less than, equal to, or greater than income. Both income and spending are in monetary terms; income received but not spent allows accumulation of money balances. Again, money matters.

For Keynes (1964), money is an asset with “special properties”: nearly zero carrying costs, elasticity of substitution, and elasticity of production. Zero carrying costs mean that it costs nothing to hold money—unlike, say, holding wheat, which would incur storage costs as well as wastage (some wheat will spoil or be lost to pests). Zero elasticity of substitution means that if you really want to hold money, there are no close substitutes to satisfy your demand. The last characteristic means that when the demand for money rises, labor is not diverted to its production. So long as there is at least one asset that is not produced by labor, it can become a bottomless sink of purchasing power, overturning Say's Law and subverting any market forces to return the system to full employment. Note that it is not important that these conditions hold strictly-there are some carrying costs of money and there are substitutes (you could hold government bonds, or bank certificates of deposit). What matters is the degree-money does have a low carrying cost, substitutes are imperfect, and almost no labor is involved in producing money (a tiny bit is required to print currency; banks have loan officers and tellers who work to create bank money). For these reasons, preference for money creates a barrier to expanding production up to the full employment point.

As mentioned, Keynes did not need to assume that expectations had been disappointed, causing production to temporarily fall below the full employment level. Indeed, after publication of the GT, he argued that he could have assumed that expectations are always fulfilled and still he would have obtained the same results. All that is necessary is that entrepreneurs cannot be sure that their expectations will be fulfilled. It is the uncertainty that generates a preference for liquid assets and thus a barrier to achieving full employment. Nor does the outcome require instability. While some of Keynes's best known passages (especially those in chapter 12 of the GT) do refer to "whirlwinds of speculation" and other examples of instability, his favorite 
explanation of equilibrium with unemployment utilized a static model in which expectations — both short run and long run—are held constant, uninfluenced by outcome. Again, firms produce only what they expect to sell at a profit, and it is not necessary for them to have been disappointed or to be subject to unstable economic forces in order for the sum of their individual production decisions to leave some labor resources unutilized.

Keynes famously remarked that no one in a Neoclassical world would hold money because there could be no value to holding a riskless (hence, low return) asset. This was later confirmed by Frank Hahn (1983), who lamented that there is no room for money in any rigorous orthodox model. Charles Goodhart (2008) insists that the possibility of default is central to any analysis of a money-using economy. As decisions about production made today commit entrepreneurs to payments in the future, there is the possibility that they will not be able to meet contractual terms. However, orthodox models explicitly rule out default, implying all IOUs are risk-free, thereby eliminating any need for the monitoring services provided by financial institutions. Not only is there no room for money in these models, there is also no need for banks or other financial intermediaries. Financial instability is also ruled out, not—as in Keynes—because instability is unnecessary to demonstrate the desired results, but because absence of the possibility of default requires perfect foresight or complete and perfect markets so that all outcomes can be hedged.

Thus, these mainstream macro models cannot incorporate the real world features that Keynes included: animal spirits and degree of confidence, market psychology, and liquidity preference. By contrast, Keynes's basic model is easily extended to account for heterogeneous credit ratings, to allow default to affect expectations, and to include "contagions" and other repercussions set off by default of one large economic entity on its commitments. The best example of such extensions is the work of the late Hyman Minsky, who developed the "Financial Instability Hypothesis" (Minsky 1986; Papadimitriou and Wray 1998). According to Minsky, the economy emerged from WWII with a very robust financial system — hardly any private debt (it had been wiped out in the Great Depression) and lots of safe and liquid federal government debt (due to deficit spending during WWII). This allowed relatively rapid economic growth without borrowing by households and firms. Various New Deal and postwar reforms also made 
the economy stable: a safety net that stabilized consumption (Social Security, unemployment compensation, welfare, and food stamps); strict financial regulation; minimum wage laws and support of unions; low-cost mortgage loans and student loans; and so on. In addition, memories of the Great Depression discouraged risky behavior.

Gradually all that changed - the memories faded, financial institutions got around regulations, the anti-government movement replaced regulation with deregulation, unions lost power and government support, globalization introduced low-wage competition and increased uncertainties, and the safety net was chronically underfunded (Minsky and Whalen 1996). Minsky believed the transformation would have occurred even without those changes, as profit-seeking firms and financial institutions would take on greater risks with more precarious financing schemes. Financial crises and recessions became more frequent and more severe, but the New Deal institutions and reforms helped the economy to recover relatively quickly from each crisis. Thus, debts built-up and fragility grew on trend over the entire postwar period. This made "it” (another Great Crash like the one that occurred in 1929) possible again. Minsky died in 1996, but it is clear that the current crisis unfolded in a manner consistent with his projections. Indeed, many have called this a "Minsky Crisis" and his name has become almost a household word—at least among those who are studying the crisis that began in 2007 (Cassidy 2008; Chancellor 2007). In other words, Minsky did “see it coming” because unlike mainstream economists, his theory included the possibility that the economy would evolve toward instability. Further, finance and money matter in his theory - as in Keynes, money is never neutral. He takes Keynes further by adding a detailed analysis of financial operations.

Keynes (1964: chapter 2) had addressed stability issues when he argued that if wages were flexible, then market forces set off by unemployment would move the economy further from full employment due to effects on aggregate demand, profits, and expectations. This is why he argued that one condition for stability is a degree of wage stickiness in terms of money. (Incredibly, this argument has been misinterpreted to mean that sticky wages cause unemployment-a point almost directly opposite to Keynes’s 
conclusion.) ${ }^{5}$ Minsky extended Keynes by arguing that if the economy ever were to achieve full employment, this would generate destabilizing forces restoring unemployment. Minsky believed that the main instability experienced in a modern capitalist economy is a tendency toward explosive euphoria. High aggregate demand and profits that can be associated with full employment raise expectations and encourage increasingly risky ventures based on commitments of future revenues that will not be realized. A snowball of defaults then leads to a debt deflation (debtors default on their debts, which are assets of creditors) and high unemployment unless there are "circuit breakers” that intervene to stop the market forces. The main circuit breakers, according to Minsky are the Big Bank (central bank as lender of last resort) and Big Government (countercyclical budget deficits) interventions (Minsky and Ferri 1991; Minsky 1986).

Finally, a technical note on Keynes’s method. Roger Backhouse (2010) has provided an excellent defense of Keynes's method, in particular, his reluctance to use mathematical models. (Keynes was a good mathematician, and his $\mathrm{PhD}$ thesis-later published-was on probability theory.) The earliest reviews of the GT actually complained about Keynes's excessive use of mathematics in the book-something the modern reader finds surprising because there are few equations (all using simple math) and only one diagram. But this is not simply because economics came to rely so heavily on mathematics. Backhouse shows that the GT is actually permeated by a mathematical way of thinking - beginning with intuition and clear thinking, with details added later as Keynes constructed incomplete models, explained mostly verbally. Keynes believed there were too many qualifications, reservations, adjustments, and interdependencies that precluded specification in formal mathematics. In other words, to keep his theory general he had to keep it somewhat vague.

It was precisely because postwar “Keynesian” economics translated the GT into algebra that it became too simplistic and specific to be relevant to our complex world. The post-1970s developments further mathematized economics in an attempt to make it

\footnotetext{
${ }^{5}$ To be clear, in the more orthodox versions of Keynes (both the Neoclassical Synthesis as well as the New Keynesian economics) unemployment is caused by sticky wages (and prices). If wages were perfectly flexible, markets would eliminate unemployment by lowering the real wage. Hence, in these versions of Keynes, the choice is either to make wages more flexible, or to use policy to ameliorate the suffering caused by unemployment. By contrast, in Keynes's theory, greater flexibility of wages would likely cause unemployment to rise! For Keynes, relative stability of wages actually improves stability of markets.
} 
ever-more rigorous. Ironically, the math became more complex but the "economy" analyzed had to be made increasingly simple. By doing so, it became concomitantly irrelevant to the complex world in which we live. The methodology adopted by orthodoxy was precisely the opposite of Keynes's methodology—it strove to have a "general” theory that begins from well-specified assumptions ("axioms"), supposedly free from institutions, culture, and habits of any specific economy. In that way, the theory could be applied to any behavior — even nonhuman behavior-at all times and places. In its most extreme version, orthodox economics became a branch of the "decision sciences," adopting methodological individualism and studying the way an optimizing “agent” (typically, Robinson Crusoe) would allocate consumption across time.

By contrast, Keynes's GT was general but at the same time institution-specific. It concerned a capitalist (or entrepreneurial) economy, that is to say one in which the purpose of production is money (production begins with money on the expectation of realizing even more money). Further, it concerns an economy operating in historical time, where the past cannot be changed and the future cannot be known. It applies to decisionmaking in an uncertain world. His methodology has been described by Jan Kregel (1976) as one of "shifting equilibrium" - taking expectations as given we can determine the point of effective demand (defined as above as the level of output and employment that would be achieved at the aggregate level if entrepreneurs were to produce the amount they expect to sell). Each change of expectations produces a new point of equilibrium (point of effective demand). There are no forces to drive this economy to the full employment level of effective demand, indeed, the dynamics are such that full employment is an unstable equilibrium, as it changes expectations in a destabilizing manner (recall Minsky's arguments about the tendency toward explosive euphoria). ${ }^{6}$

\footnotetext{
${ }^{6}$ So by contrast with orthodox methodology, Keynes's methodology makes room for issues such as path dependency, hysteresis, true uncertainty, and expectation formation in situations of "unknowledge."
} 


\section{KEYNES AND POLICY}

Keynes had long rejected the notion of laissez-faire, writing a pamphlet titled "The End of Laissez-Faire" in 1926. Not only did he argue against that the claim that some "invisible hand" could guide self-interested individuals to behave in the public interest, he denied that these individuals even knew their own self-interest. He went further, arguing that the notion of laissez-faire had never really been embraced by economists. Rather it was adopted by ideologues. To be sure, in that 1926 piece Keynes did not provide a convincing rebuttal to the laissez-faire doctrine, nor did he provide a policy solution. His theory of effective demand had to wait another decade. It was only with his publication of the GT that Keynes made it clear why the invisible hand would fail, and why government had to play a positive role in the economy.

Keynes's impact on postwar policy was at least as great as his impact on theory. Of course, it is questionable whether much of the policy that was called Keynesian really had strong roots in Keynes's GT. Still, the influences of Keynes's work on domestic fiscal and monetary policy, on the international financial system, and on development policy—especially in Latin America—cannot be denied. If we take the central message of the GT as the proposition that entrepreneurial production decisions cannot be expected to generate equilibrium at full employment, then the obvious policy response is to use government to try to raise production beyond the level "ground out" by market forces. Unfortunately, "Keynesian” policy was eventually reduced to overly simplistic metaphors such as "pump-priming" and "fine-tuning" that would keep aggregate demand at just the right level to maintain full employment. It is now commonplace to claim that Keynesian policy was tried, but failed.

In practice, postwar policy usually consisted of measures to promote saving and investment. The first was wholly inconsistent with Keynes, based instead on the neoclassical loanable funds view that saving "finances" investment; the second was based on a multiplier view that, while somewhat consistent with Keynes's explication of the determination of the equilibrium level of output, relied on overly simplistic views of entrepreneurial expectation formation while ignoring important stability questions. First, there is no reason to believe that the demand (or multiplier) effect of investment will be 
sufficient to absorb the additional capacity generated by the supply effect of investment. There are a number of related avenues of research—ranging from Alvin Hansen's stagnation thesis (modern capitalism tends to stagnate due to lack of investment opportunities), to a Keynesian “disproportionalities” argument that such gross policy measures would generate the wrong mix of productive capacity relative to demand, to the Harold Vatter and John Walker view that sustaining adequate rates of growth through time would require continuous growth of the government sector relative to growth of the private sector (Wray 2008b).

Second, attempting to maintain full employment by stimulating private investment would shift the distribution of income toward owners of capital, worsening inequality and thereby lowering the society's propensity to consume-one of the problems addressed by Keynes in chapter 24 of the GT. For example, work based on Michal Kalecki’s (1971) profit equation shows how higher investment rates generate higher profit rates, and shifts the distribution of income toward entrepreneurs and away from workers. There are also two kinds of sectoral issues raised. A high investment strategy will tend to favor capital-intensive industries, shifting the distribution of income toward higher-paid and unionized workers. The sectoral balances approach implicitly adopted by Minsky (1963) in his earliest work, and developed in detail by Wynne Godley, carries the Kalecki analysis further by examining the implications for financial balances implied by spending growth (Godley and Wray 2000). For example, an expansion led by private sector deficit spending (with firms borrowing to finance investment in excess of internal income flows) implies that the government and/or the external sector will record equivalent surpluses (a government budget surplus and/or a capital account surplus). This then raises sustainability issues as private debt will grow faster than private sector income. Indeed, this is exactly what happened in the decade after 1996 in the United States (and some other nations), helping to create the overindebtedness that led to our financial crisis (Wray 2003b).

Third, Minsky’s financial instability hypothesis raises related concerns. Over the course of an economic boom that is led by investment spending, private firms stretch liquidity (income flows are leveraged by debt, and the ratio of safe assets to liabilities rises), leading to increasingly fragile financial positions. Combining the financial 
instability hypothesis with the Godley sectoral balances approach, it is apparent that the government budget plays an important role in cooling a boom: rapid growth of income moves the government budget toward balance and even to a surplus. The mostly unrecognized flip-side to a government sector surplus is a private sector deficit (holding the foreign balance constant), so "improvement” of government balances must mean by identity that nongovernment balances become more precarious. Followers of the work of Minsky and Godley were thus amused by positive reactions to the Clinton-era budget surpluses, and the predictions that all federal government debt would be eliminated over the coming decade and a half. It was no surprise that the Clinton surpluses killed the boom and morphed into budget deficits, since the budget automatically moves toward larger deficits in a slump, maintaining profit flows and strengthening private balance sheets that accumulate net wealth in the form of safe government bonds (Wray 2003b).

Hence, the heterodox approach that follows Keynes and Minsky is skeptical that the private sector can be a reliable engine of growth. It is also skeptical of a "pumppriming” approach to government policy. Rather, policymaking is going to have to be specific, with well-formulated regulations to constrain private firms and with welltargeted government spending. The wholesale abandonment of regulation and supervision of the financial sector has proven to be a tremendous mistake. Left to supervise itself, Wall Street created complex and exceedingly risky financial instruments that allowed it to burden households and nonfinancial firms (as well as state and local governments) with debt (Wray 2009). Wall Street also managed to shift the distribution of income toward its traders and CEOs_-just before the financial crash, the financial sector captured $40 \%$ of all corporate profits in the United States. The debt to GDP ratio rose to 500\% (versus 300\% in 1929 on the eve of the Great Depression). Income inequality rose to levels not seen since 1929—with poverty rising in the midst of plenty. Even though Wall Street was booming, real economic growth was not particularly good in the period before the crash, and the average real wage of workers was no higher than it had been back in the early 1970s. While official unemployment was relatively low, unmeasured unemployment and underemployment has been rising on trend (Wray 2003a). It is clear that fundamental reform of the financial sector-on a scale similar to what was done in 
the 1930s — will be required to get the American economy back on track. A similar story can be told about all the advanced capitalist economies.

In addition, we need to do something about the rest of the economy to create jobs and rising living standards. If heterodox economists do not believe that "fine-tuning" is possible, what can be done? First, policy should address the obvious areas that have been neglected for more than three decades as well as new problems that have emerged. America's public infrastructure is entirely inadequate-with problems ranging from collapsing bridges and levees, to overcrowded urban highways and airports, an outdated electrical grid, and lack of a highspeed rail network. Global warming raises new problems that need to be addressed: moving to cleaner energy production, expanding public transportation, retrofitting buildings to make them energy efficient, and reforestation. In all of these areas, government must increase its spending-either taking on the projects directly or subsidizing private spending. Because this spending will help to make America more productive, the spending will be more effective than general pump-priming and will not suffer from the drawbacks discussed above.

Still, it is likely that even if all of these projects are undertaken, millions of workers will be left behind. First there is no reason to believe that the additional demand for labor will be sufficient to create enough jobs; second, there can be a skills mismatch, problems of discrimination (against ethnic groups, by gender, against people with disabilities, and against people with low educational attainment or criminal records), and geographic mismatch (jobs need to be created where the unemployed live). For this reason, many heterodox economists have revived Minsky’s call for an “employer of last resort” (Minsky 1965; Wray 1998; Kelton and Wray 2004; Harvey 1989). Minsky argued that only the federal government can offer an infinitely elastic demand for workershiring anyone ready and willing to work — at a decent wage. This is also called a job guarantee program. The idea is that the federal government provides funding for a basic (living) wage with benefits. Creation and administration of the program, as well as supervision of the workers in the program, could be highly decentralized to local not-forprofit agencies, community development organizations, and state and local governments. The program would take “workers as they are”-designing jobs to fit the worker's needs and abilities. There would be no skills or education requirement, although all jobs would 
provide training and perhaps even basic education. Jobs would be created where the workers live. Flexible work arrangements could be made (such as part-time jobs) to fit the needs of working mothers (and even students of working age). The jobs could include some of those listed above (retrofitting homes with insulation, for example) but would be expanded to include provision of public services — child and aged care, "meals on wheels” (delivering hot meals to aged, infirm, and those otherwise confined to their homes due to disabilities), playground and subway supervision, litter clean-up, and so on.

All of this could require more government spending (although it is possible that reducing spending in areas that do not generate jobs and that do not enhance US production and living standards would partially offset the additional spending). While orthodoxy fears budget deficits (with many arguing that they only "crowd-out” private spending), heterodox economists argue that orthodoxy conflates government budgets with household budgets. A sovereign government's budget is not like the budget of a household or firm. Government issues the currency, while households and firms are users of that currency. As the Chartalist or Modern Money approach explains, modern governments actually spend by crediting bank accounts (Bell 2000; Wray 1998). It really just amounts to a keystroke, pushing a key on a computer that generates an entry on someone’s balance sheet. Government can never run out of these keystrokes. Remarkably, even the Chairman of the Fed, Ben Bernanke, testified to Congress that the Fed spends through simple keystrokes—-hence could afford to buy as many assets as necessary to bail-out Wall Street's banks. All that is necessary is to recognize that the Treasury spends the same way, and then Washington's policymakers could stop worrying about "affordability" of the types of programs that everyone recognizes to be necessary: public infrastructure investment, “green” investments to reduce global warming, and job creation. To be sure, this is not a call for "the sky is the limit" spending by government. Too much spending will be inflationary and could cause currency depreciation. Government spending must be well-targeted and must not be too large. How big is too large? Once productive capacity is fully used and the labor force is fully employed, additional spending would be inflationary.

This is also called the "functional finance" approach to policy, developed by Abba Lerner (1943, 1947). Policy should be directed to resolving problems, raising living 
standards, and achieving the public purpose as defined by the democratic process. There should be no preconceived budgetary outcome — such as a balanced government budget over a year or over the cycle. In other words, the goal should be to use the government's "purse” to achieve the public purpose-not to mandate any specific dollar amount for spending or for its deficit. This does not mean that government spending on programs should not be constrained by a budget-Congress needs to approve the budgets for individual programs, and then hold program administrators accountable for meeting the budgets. The purpose of budgeting is not to ensure that the overall federal government budget balances, but rather to reduce waste, graft, and corruption. Budgeting is one means of controlling projects to help ensure they serve the public interest. Unlike the case of a household or firm, the sovereign government can always "afford" to spend more on a program—but that does not mean it should spend more than necessary.

In conclusion, most economists “didn’t see it coming” because their approach to economics denies that "it" could happen. The Neoclassical approach that provides the foundation for all mainstream macroeconomics is applicable only to an imaginary world, an economy focused on market exchange based on a barter paradigm. Money and finance are added to the model as an afterthought - they really do not matter. Because an invisible hand guides rational individuals who have perfect foresight toward an equilibrium in which all resources are efficiently allocated, there is little role for government to play.

The current crisis has shown this approach to be irrelevant for analysis of the economy in which we live. By contrast, the Keynesian revolution that began with the GT offered an alternative that does allow us to understand the world around us. Keynes's different methodological approach allowed him to develop a theory that was at the same time "general" but also "specific" in the sense that it incorporated those features of the capitalist (entrepreneurial) economy that cause it to move toward crisis. Economists working in that tradition did see "it" coming, and they have offered policy advice that would help to get the economy back on track and to reform it so that it would not only be more stable, but also so that it would operate in the interest of most of the population. 


\section{REFERENCES}

Backhouse, Roger E. 2010. "An abstruse and mathematical argument: the use of mathematical reasoning in the General Theory." in Bradley W. Bateman, Toshiaki Hirai, and Maria Cristina Marcuzzo (eds.), The Return to Keynes. Cambridge, MA and London: The Belknap Press of Harvard University Press.

Bell, Stephanie. 2000. “Do taxes and bonds finance government spending?” Journal of Economic Issues 34: 603-620.

. 2001. "The role of the state and the hierarchy of money." Cambridge Journal of Economics 25(2): 149-163.

Brunner, Karl. 1968. “The role of money and monetary policy.” Federal Reserve Bank of St. Louis Review 50(July): 9.

Cassidy, John. 2008. “The Minsky moment.” The New Yorker, Feb 4. Available at: www.newyorker.com (accessed 1/29/2008).

Chancellor, E. 2007. “Ponzi Nation.” Institutional Investor, Feb 7.

Fama, E.F. 1970. "Efficient capital markets: A review of theory and empirical work." Journal of Finance 25(2): 383-417.

Forstater, Mathew, and L. Randall Wray. 2008. Keynes for the Twenty-First Century: the continuing relevance of "The General Theory." London: Palgrave/Macmillan.

Friedman, M. 1969. “The optimum quantity of money.” in M. Friedman (ed.), The Optimum Quantity of Money and Other Essays. Chicago: Aldine.

Galbraith, John K. 1961. The Great Crash, 3rd ed. Cambridge, MA: The Riverside Press.

Godley, Wynne, and L. Randall Wray. 2000. “Is Goldilocks Doomed?” Journal of Economic Issues March.

Goodhart, Charles A.E. 1998. "Two concepts of money: implications for the analysis of optimal currency areas." European Journal of Political Economy 14: 407-432.

_. 2008. "Money and Default.” in Mathew Forstater and L. Randall Wray (eds.), Keynes for the Twenty-First Century: the continuing relevance of "The General Theory." London: Palgrave/Macmillan.

Hahn, Frank. 1983. Money and Inflation. Cambridge, MA: MIT Press.

Harvey, Phillip. 1989. Securing the Right to Employment. Princeton: Princeton University Press. 
Kalecki, M. 1971. "The determinants of profits.” in M. Kalecki (ed.), Selected Essays on the Dynamics of the Capitalist Economy. Cambridge, UK: Cambridge University Press.

Kelton, Stephanie, and L. Randall Wray. 2004. "The War on Poverty after 40 Years: A Minskyan Assessment.” Public Policy Brief 78. Annandale-on-Hudson, NY: Levy Economics Institute of Bard College.

Keynes, John Maynard. 1964. The General Theory of Employment, Interest and Money. New York and London: Harcourt Brace Jovanovich.

Kregel, J.A. 1976. "Economic methodology in the face of uncertainty: The modeling methods of Keynes and the Post-Keynesians." Economic Journal 86(342): 209225.

Lerner, Abba P. 1943. "Functional finance and the federal debt.” Social Research 10: 3851.

. 1947. "Money as a creature of the state." American Economic Review 37: 312-317.

Mankiw, Gregory. 2008. Principles of Macroeconomics, 5th ed. Mason, OH: Cengage Learning.

Minsky, H.P. 1963. “Discussion.” American Economic Review 53(2): 401-412.

. 1965. "The Role of Employment Policy.” in Margaret S. Gordon (ed.), Poverty in America. San Francisco: Chandler Publishing Company.

. 1986. Stabilizing an Unstable Economy. New Haven, CT: Yale University Press.

Minsky, H.P., and P. Ferri. 1991. "Market Processes and Thwarting Systems.” Working Paper 64. Annandale-on-Hudson, NY: Levy Economics Institute of Bard College.

Minsky, H.P., and C. Whalen 1996 "Economic Insecurity and the Institutional Prerequisites for Successful Capitalism.” Working Paper 165. Annandale-onHudson, NY: Levy Economics Institute of Bard College.

Papadimitriou, Dimitri B., and L. Randall Wray. 1998. "The economic contributions of Hyman Minsky: varieties of capitalism and institutional reform.” Review of Political Economy 10(2): 199-225.

Patinkin, Don. 1965. Money, Interest and Prices, 2nd ed. New York: Harper and Row.

Samuelson, Paul. 1973. Economics, 9th ed. New York: McGraw-Hill. 
Skidelsky, Robert. 2009. Keynes: the Return of the Master. New York: Public Affairs, Perseus Books Group.

Snowdon, Brian, and Howard R. Vane. 2006. Modern Macroeconomics: Its Origins, Development and Current State. Cheltenham, UK: Edward Elgar.

Wray, L. Randall. 1998. Understanding Modern Money: The Key to Full Employment and Price Stability. Northampton, MA.: Edward Elgar.

— . 2003a. "Can a Rising Tide Raise All Boats? Evidence from the KennedyJohnson and Clinton-era Expansions.” in Jonathan M. Harris and Neva R. Goodwin (eds.), New Thinking in Macroeconomics: Social, Institutional and Environmental Perspectives. Northampton, MA.: Edward Elgar.

—. 2003b. “The Perfect Fiscal Storm.” Challenge 46(1): 55-78.

. 2004. "The Fed and the New Monetary Consensus: The Case for Rate Hikes, Part Two.” Public Policy Brief 80. Annandale-on-Hudson, NY: Levy Economics Institute of Bard College.

. 2008a. “Lessons from the subprime meltdown.” Challenge 51(2): 40-68.

. 2008b. "Demand Constraints and Big Government.” Journal of Economic Issues xlii(1): 153-173.

. 2009. "The rise and fall of money manager capitalism: a Minskian approach." Cambridge Journal of Economics 33(4): 807-828. 